\title{
Analysis of Early Childhood Tutorial Content to Improve Reading, Writing, and Arithmetic Skills
}

\author{
Luhung Kawuryaning Pertiwi ${ }^{1, *}$, Heny Djoehaeni ${ }^{2}$ \\ ${ }^{1,2}$ Department of Early Childhood Education, School of Postgraduate, Universitas Pendidikan Indonesia \\ *Corresponding author. Email: luhungkawuryaning@ upi.edu
}

\begin{abstract}
Every parent expects their child to give good academic skills. The characteristics of a child with the academic skills trusted by most parents are to have the ability to read, write and arithmetic to be able to continue the desired elementary school. The phenomenon of elementary school admission requirements with academic tests is reading, writing and arithmetic, which makes some parents choose to guide their children with additional learning through study tutoring or reading, writing and arithmetic and arithmetic courses. This article aims to provide an overview or the tutoring of early childhood studies, both of which have been implemented in formal and non-formal institutions based on the results of research conducted by previous researchers. The method used in this article is a literature study of early childhood tutoring problems. The results of the literature study show that early childhood tutoring to improve reading, writing and arithmetic skills has various strategies. The presence of tutoring is becoming one of the solutions so that children can enter a favourite elementary school because most elementary schools have qualified new learners to take the academic skills in order to be able to enter the desired elementary schools, as well as understanding of government policy in terms of acceptance of elementary school students.
\end{abstract}

Keywords: Academic skills, early childhood tutoring.

\section{INTRODUCTION}

The phenomenon of an academic test as the acceptance requirement for new students in elementary school is a concern for parents to their children to have high academic skills. It is the problem until the pro cons arise about the academic test as a requirement for the new admission of elementary school which is considered to be the only solution for children to enter elementary school. Whereas early childhood education (ECE) learning covers all aspects of child development and for academic skills are only introduced through fun activities. The existence of private tutoring for early childhood because of the selection of elementary school in the district of Pekalongan, most of the applying selection of reading, writing and arithmetic skills [1]. This phenomenon is a test of ECE learners on how the strategy is used to convince parents that children have the ability to read, write, and calculate to prepare them for the next level of education.

Previous research showed that stimulation of early literacy skills performed by teachers in schools outside school hours with some media, the simulation results are quite successful by the dominant obstacle in stimulation is that the children are not focused, bored, sleepy, and happier to play than reading [2]. Although from the study there are some children who are not bored, more who feel the saturation if they get additional learning is not a fun activity, there is no playing element, while early childhood learning has the principle of learning through the game.

As explained in the results of the research, literacy skills or cognitive skills in early childhood, which means reading, writing and arithmetic skills. But the focus of literacy skills on the research above is only on reading skills. Literacy skills as emergent literacy, where emergent literacy is an early childhood skill to read and write to pursue elementary school education [3]. Literacy has two definitions, namely the old definition and the evolving definition [4]. The old definition of literacy is the ability to read and write, while the definition of literacy divided into several areas of ability including science literacy, computer literacy, information literacy, virtual literacy, mathematics literacy, and so on. So the similarities of both views on literacy are reading and writing skills.

This article aims to explain the tutoring of early childhood studies, both of which have been applied by ECE units and non-formal institutions based on the 
results of research conducted by previous researchers. Masturoh [5] said that reading, writing and arithmetic activities are carried out by tutoring institutions to answer the needs of children in Gresik, East Java who think reading, writing and arithmetic skills need to be given early on. Fajhriani \& Nasrul [6] explained that The AHE Cendekia Tutoring Institute in Padang teaches early childhood reading skills using the AHE method, one of which uses AHE cards. Meanwhile, Amini [7] explained about reading, writing and arithmetic learning conducted by formal institutions outside of school hours, where teachers provide additional learning in accordance with the wishes of parents.

\section{METHOD}

The method used in this article is a literature study of early childhood tutoring problems that are considered to be a solution in improving reading, writing and arithmetic skills, as well as government policies that apply about the acceptance of new learners from elementary school. So, the description of this article contains the results of a literature study on the current phenomenon of the day that parents and teachers understand the application of additional learning for early childhood with the aim of being able to enter the desired elementary school and understand the policy government in terms of acceptance of new students in elementary school. The references used in this article are journals, seminar proceedings, and thesis as the development of the scope that has been compiled by the authors. The scope of this article includes reading, writing and arithmetic skills for early childhood and early childhood tutoring. The authors try to provide a detailed understanding of how early childhood tutoring content and solutions develop reading, writing and arithmetic skills for early childhood.

\section{READING, WRITING, AND ARITHMETIC SKILLS FOR EARLY CHILDHOOD}

Reading, writing and arithmetic skills for early childhood is stated in Peraturan Menteri Pendidikan dan Kebudayaan Republik Indonesia (PERMENDIKBUD RI) No. 137 year 2014 about national standard of early childhood education chapter IV concerning the standard content of article 10 paragraph $4 \mathrm{c}$ which read: "Think symbolic, include the ability to know, mention and use the concept of numbers, know the letters, and be able to represent" [8]. And the 5c verse reads: "Literacy includes an understanding of the relationship of form and tone of letters, imitating the form of letters, and understanding the word in the story" [8]. Reading is an activity that includes word recognition, literal understanding, understanding the meaning of reading and the mark or emblem contained in reading [9]. The initial for children is differentiating letters in the alphabet, writing activities starting from scribble and creating shapes, as well as counting activities to sum, subtract and change numbers [10]. So that reading, writing and arithmetic skills is the child's ability to understand the understanding of letters, words and readings, then learn to write and count the numbers.

Seeing the phenomenon of the test for elementary school admission, increase reading, writing and arithmetic skills in early childhood has been described by some researchers, namely to assist the children in continuing elementary school, because some elementary schools apply the academic test as the size of early childhood is considered capable of continuing education to elementary school. Some parents choose schools in kindergarten that teach read, writing arithmetic so that children can enter a favourite elementary school [11]. Read, write and arithmetic learning is a requirement of an elementary school that applies a new student acceptance requirement with reading, writing and arithmetic test [12]. Reading, writing and arithmetic is very important for early childhood to continue the next level of education, namely elementary school education [13].

Some research-related tests for elementary school admission that make an ECE unit give thorough learning on the aspects of development proves that some parties are too focused on reading, writing and arithmetic skills as a reference to early childhood's skills. The development of reading, writing and arithmetic that is relevant for early childhood is through play activities that stimulate all aspects of the development of children who have been listed in PERMENDIKBUD RI No. 137 year 2014, including aspects of moral and religious development, physical motor, cognitive, language, social-emotional, and $\operatorname{art}^{8}$. For example, reading, writing and arithmetic learning can be given in the form of a game, by counting the number of steps used by interesting media [14]. The development of reading, writing and arithmetic is done through the game "Ayo Kita Temukan" with A-Ba-Ca board, a smart box containing objects, letters and numbers, pictorial paper, and a white sheet of paper to write letters and words [15].

Earlier studies have stated that Montessori methods apply to learn through play, in which the study of reading and writing began pre-reading and pre-writing using various media, as well as learning to count abstract concepts with the media [16]. A more specific example is reading the fairy tale so that the child is motivated to read [17]. So that reading, writing and arithmetic skills for early childhood can be developed through play. Basically, early childhood gained learning through the game because the children learn based on the experience experienced and associated with all aspects of development. 


\section{EARLY CHILDHOOD TUTORING}

The presence of early childhood tutoring gave rise to pro-cons of early childhood tutoring that expressed as one solution for children can improve reading, writing and arithmetic skills. The sense of tutoring is to help or alternatives for children who teach about children's school learning outside school hours. Tutoring is a nonformal study outside school hours so that children learn not only in school [18]. Another sense of tutoring is the service organized by the school in order to solve the difficulties of children in learning [19]. Tutoring leads to emotional skill [20]. Tutoring focuses on improving reading and writing skills [21]. From the different perceptions of early childhood tutoring, it can be concluded that tutoring has different places and objectives on each organizer. Tutoring is available in formal schools conducted after school hours, and in nonformal institutions in the form of a stand-alone reading, writing and arithmetic course, not from a formal school. Even in terms of different objectives, tutoring in the formal school has a focus on the children's developmental aspects, while tutoring on non-formal institutions focuses on reading, writing and arithmetic.

Some parents and teachers agree that early childhood tutoring can improve their reading, writing and arithmetic skills and become the best solution for children to have the maximum skills to enter the desired elementary school. Early childhood learning emphasizes reading, writing and arithmetic courses, making it a demand for teachers to focus on providing learning about read, write and arithmetic [22]. Parents agree that tutoring will make children more readily continue the education level of elementary school [23]. The results of previous research showed that high academic skill is very important so that children can continue their education to a favourite elementary school [24]. Other previous research results also show that more percentage of parents who consider reading, writing and arithmetic is very important, because reading, writing and arithmetic are indispensable for children to prepare for the best of continuing elementary school [25]. So the presence of tutoring makes parents prioritize children in tutoring.

The example of tutoring conducted by ECE units are extracurricular. The extracurricular activity of colouring is carried out outside teaching and learning activities are not compulsory for children [26]. Extracurricular activities are an example of tutoring because the research objectives of the colouring activity is in order to increase the aspect of cognitive development. While tutoring on non-formal institutions or courses of reading, writing and arithmetic has clearly focused on reading, writing and arithmetic activities. The similarities are both implemented outside school hours and are not mandatory. The difference is tutoring in the ECE unit an activity that covers the children's development aspect and aims to increase the interest and talent of children, while tutoring in non-formal institutions only focuses on reading, writing and arithmetic skills, also aims to facilitate children have the maximum academic skill to enter a favourite elementary school. The counter insurgency of early childhood learning is the learning that is applied by some non-formal institutions, where the lesson focuses solely on reading, writing and arithmetic skills.

Some of previous opinions and research results that have been described show that early childhood tutoring is not required if the service is the questions that must be resolved by the children. In contrast, tutoring is a solution for early childhood who have difficulty in developing aspects of development if the service is carried out through playing activities. But some factors that must be considered to implement early childhood tutoring, including the basic principle of guidance, the essence of guidance, orientation guidance, the concept of implementation of guidance, the form of guidance services, and the setting of guidance services [27]. The basic principles of guidance is the unit of ECE provides tutoring that is implemented during teaching and learning activities. The purpose of guidance is the guidance of learning is given to children who have a delay in developmental aspects to well-developed children.

Then the concept of the implementation of guidance should be understood by parents because children's skills are different from their friends. This form of guidance services means child development data services, insight development services for children and parents, and treatment services or activities for children. The last is the setting of guidance service in the form of individuals or groups, according to the needs of each child.

Furthermore, it is counter to the phenomenon of elementary school entrance tests which is the regulation of elementary school institutions that apply academic proficiency tests as a requirement for elementary school, while the government does not require elementary school institutions to apply academic skill's tests. Explained in PERMENDIKBUD RI No. 44 year 2019 about acceptance of new students in kindergarten, elementary school, junior high school, senior high school, vocational high school chapter II procedures for acceptance for new students' part one about the requirements of article 5 paragraph 1, 2, 3 and 4 which reads [28]:

1) The requirement of prospective new students' class 1 (one) elementary school-aged:

a) 7 (seven) years to 12 (twelve); or

b) At least 6 (six) years on 1 July of the year.

2) The school must accept learners who are 7 (seven) years old to 12 (twelve) years old.

3) The exclusion of the minimum age requirement of 6 ( six) years as referred to in paragraph 1) letter $b$ is at least 5 (five) years 6 (six) months 
on 1 July the current year that is intended for prospective learners who have the potential intelligence and/or special talent and physic preparedness as evidenced by the written recommendation of professional psychology.

4) In the case of professional psychologists as referred to in paragraph 3) are not available, recommendations may be made by the school teacher council.

Judging from the government regulations above there are no requirements of prospective students of elementary school with reading, writing and arithmetic skills. Although there are various new admission lines, there is still no such requirement, except if originating from abroad, as described in PERMENDIKBUD RI No. 44 year 2019 about the acceptance of new learners in kindergarten, elementary school, junior high school, senior high school, and vocational high school chapter IV of student migration article 34 paragraph 1a, 1b and 1c, which reads [29]:

1) Students in elementary school in other countries may transfer to elementary school in Indonesia after fulfilling:

a) Statement letter for principal;

b) Certificate from director general who handles the field of primary and secondary education; and

c) Passed the feasibility and placement tests that the school organized.

The feasibility test written above can be a test of academic skills. But not written in children who are not moving from aboard. Therefore, the academic skill test is the policy of the institution of the elementary school, not the obligation of the government, because the government has asserted through the regulations that have been outlined before. Therefore, government policy has been in sync in response to ECE learning and elementary school entry requirements, only the elementary school institutions should understand the ECE learning policy and elementary school entry requirements so that the objectives of ECE learning can be applied and continued to the next education level of elementary school. If there are still academic tests to continue elementary school, ECE learning will change to focus only on reading, writing and arithmetic skills.

Looking at the number of elementary schools that provide academic skill tests as a condition of acceptance of new learners, examining early childhood skills who deserved to pursue an education in elementary school can be done by giving tests such as Nijmeegse School Bekwaamheids Tests (NST). NST is a child readiness test continuing education to elementary school, in the test there are several test pages with questions about distinguishing shapes, colours, imitating strokes, completing images, finding the same shapes, and understanding the content of the story [29]. The children working on NST are given either right or wrong, not all should be outlined or like an essay. The NST presented is interesting as each page is given a title and image known to the child, such as a fish page, a flower page, and so on.

NST aims to see the maturity of all aspects of child development [30]. So, the test can be given because it complies with government policies regarding the learning system of ECE and the requirements of new learners of elementary school level.

\section{CONCLUSION}

Reading, writing and arithmetic skills are very important for parents so that children can enter the desired elementary school. However, the government does not require the acceptance of new elementary school students in the form of an academic proficiency test. So these requirements are the policy by the elementary school. And need to be considered for the elementary school on the prevailing government policy, because government policy in ECE and the elementary school needs to be understood by both institutions. The child readiness test to enter elementary school can be a psychological test, namely the Nijmeegse Schoolbekwaamheid Test (NST). In NST there is a choice to answer tailored to all aspects of children's development, not the questions that require the children to write and perform the counting operation.

Early childhood tutoring or reading, writing and arithmetic courses are the service of ECE units and nonformal institutions to improve the child's developmental aspects as well as children's interests and talents. The form of tutoring from ECE units is usually extracurricular, while the form of tutoring from nonformal institutions is only a course of reading, writing and arithmetic. Tutoring will not be a solution for children with the delay in development if only focus on reading, writing and arithmetic skills, so that conducting the underlying concept of implementation guidance, the form of guidance services, and the setting of guidance services.

\section{REFERENCES}

[1] Istiyani D. Model pembelajaran membaca menulis menghitung (calistung). Jurnal Penelitian. 2013;10(1):1-18.

[2] Mulat ES. Proses stimulasi kemampuan literasi awal anak prasekolah oleh guru PAUD di sekolah. Indonesia (ID): Universitas Muhammadiyah Surakarta, 2017. 17 p. Report No: 2.

[3] Fajriyah L. Pengembangan literasi emergen pada anak usia dini, In Proceedings of ICECRS [Internet]. 
2018 March [cited 2020 Sept 14];1(3):165-172. Available from: http://ojs.umsida.ac.id/index.php/ icecrs DOI: 10.21070/picecrs.v1i3 .1394.

[4] Basyiroh I. Program pengembangan kemampuan literasi anak usia dini. Tunas Siliwangi. 2017;3(2):120-134.

[5] Masturoh U. Fenomena orang tua mengikutsertakan anak usia TK (usia 4-6 tahun) belajar ekstra calistung. Journal of Childhood Education. 2018 [cited 2021 Jan 1];2(1):1-11. Available from: http://journalfai.unisla.ac.id/index.php/jce/article/vi ew/19 DOI: https://doi.org/10.30736/jce.v1i2.19.

[6] Fajhriani D, Nasrul F. Peningkatan kemampuan membaca anak dengan menggunakan metode AHE dan implikasinya terhadap layanan penguasaan konten. Ed-Humanistics: Jurnal Ilmu Pendidikan. 2020 Apr [cited 2021 Jan 1];5(1):638-644. Available from: http://ejournal.unhasy.ac.id/index.php/edhumanistics/article/view/704 DOI: https://doi.org/1 0.33752/ed-humanistics.v5i1.704.

[7] Amini M. Profil keterlibatan orang tua dalam pendidikan anak usia TK. Jurnal Ilmiah VISI PPTK PAUDNI. 2015 Jun [cited 2021 Jan 1];10(1):9-20. Available from: http://journal.unj.ac.id/unj/ index.ph p/jiv/article/view/3738 DOI: https://doi.org/10.2100 9/JIV.1001.2

[8] Ministry of Education and Culture. Peraturan menteri pendidikan dan kebudayaan Republik Indonesia Nomor 137 Tahun 2014. Indonesia (ID): Ministry of Education and Culture; 2014. 76 p. Report No: 1668.

[9] Aulina CN. Pengaruh permainan dan penguasaan kosakata terhadap kemampuan membaca permulaan anak usia 5-6 tahun. Pedagogia. 2012;1(2):131-143.

[10] Pratiwi E. Pembelajaran calistung bagi anak usia dini antara manfaat akademik dan resiko menghambat kecerdasan mental anak, In Seminar Nasional Pendidikan. 2015 Nov [cited 2020 Sept 9];1(1):278283. Available from: http://seminar.umpo.ac.id/ index.php/semnasdik2015/article/viewFile/231/231.

[11]Zubaidah S, Nasuhah L. Karakteristik pendidikan anak usia dini. Jurnal Al-'Adalah. 2016;19(2):269284.

[12] Widyastuti A. Implementasi program parenting tentang stimulasi, membaca, menulis, berhitung bagi orang tua dan guru PAUD Limo Depok. Jurnal Terapan Abdimas. 2018 [cited Sept 9];3(1):66-71. Available from: http://e-journal.unipma.ac.id /index.php/JTA/article/view/2170 DOI: http://doi.o rg/10.25273/jta.v3i1.2170.

[13] Pentury HJ. Pengembangan literasi guru PAUD melalui bahan ajar membaca, menulis, dan berhitung di Kecamatan Limo dan Cinere. Jurnal Pengabdian Kepada Masyarakat. 2017 [cited 2020 Sept
10];1(1):14-21. Available from: http:// journal. pnm .ac.id/index.php/dikemas/article/view/167.

[14]Faroqi A, Maula B. Aplikasi multimedia interaktif pembelajaran membaca, menulis, berhitung (calistung). Jurnal ISTEK. 2014 Aug [cited 2020 Sept 10];8(2):229-245. Available from: https:// journal.uinsgd.ac.id/index.php/istek/article/view/23 0 .

[15] Sugiono S, Kuntjojo K. Pengembangan model permainan pra-calistung anak usia dini. Jurnal Pendidikan Usia Dini. 2016 Nov [cited Sept 9];10(2):255-276. Available from: http:// journal.unj .ac.id/unj/index.php/jpud/article/view/136.

[16] Darnis S. Aplikasi Montessori dalam pembelajaran membaca, menulis, dan berhitung tingkat permulaan bagi anak usia dini. Jurnal Caksana: Pendidikan Anak Usia Dini. 2018 Jun [cited Sept 9];1(1):1-10. Available from: http://trilogi.ac.id/journal/ ks/index. php/PAUD/article/view/3 DOI: https://doi.org/10.3 1326/jcpaud.v1i01.3.

[17] Wildova R, Kropackova J. Early childhood prereading literacy development. Procedia-Social and Behavioral Sciences. 2015 Jun [cited 2020 Sept 11];191(2):878-883. Available from: https://www. sciencedirect.com/science/article/pii/S18770428150 26786 DOI: https://doi.org/10.1016/j.sbspro.2015. 04.418

[18] Sandi NV, Setyorini R. Analisis kegiatan bimbingan belajar pada anak usia dini dalam kreativitas pembelajaran finger painting. Generasi Emas: Jurnal Pendidikan Islam Anak Usia Dini. 2018 Oct [cited 2020 Sept 9];1(2):120-135. Available from: https://journal.uir.ac.id/index.php/generasiemas/arti cle/view/2749 DOI: https://doi.org/10.25299/ge. 20 18.vo1(2).2749

[19]Putri SA. Bimbingan belajar melalui permainan ular tangga untuk meningkatkan kemampuan mengenal abjad pada anak autis di PAUD Inklusi Melati Sidoarjo. Indonesia (ID): Universitas Islam Negeri Sunan Ampel Surabaya; 2010.

[20]Nuranini P, Tawil T. Bimbingan belajar melalui bermain peran berbasis islam untuk meningkatkan kecerdasan emosional AUD. Unimma Journal. 2017;9(1):17-23.

[21]Novianti E, Wahid S, Jalius. Gambaran kinerja pendidik di bimbingan minat baca dan belajar (BIMBA) AIUEO Kota Padang. Jurnal Pendidikan Luar Sekolah. 2018 Jun [cited 2020 Sept 11];1(2):162-170. Available from: http://ejournal .unp.ac.id/index.php/pnfi/article/view/9059 DOI: https://doi.org/10.24036/ spektrumpls.v1i2.9059.

[22] Marlisa L. Tuntutan calistung pada anak usia dini. Jurnal Ilmiah Tumbuh Kembang Anak Usia Dini. 2018 Jun [cited 2020 Sept 20];1(3):25-38. Available 
from: http://ejournal.uin-suka.ac.id/ tarbiyah /index .php/goldenage/article/view/1928.

[23] Subekti I. Persepsi orang tua terhadap kesiapan sekolah (school readiness) anak usia 5-6 tahun. Indonesia (ID): Universitas Negeri Jakarta. Report No: 23.

[24]Fatimah S, Nurhadi, Liestyasari SI. Motif 'agar' dan motif 'karena dalam keputusan orang tua memilih lembaga bimbingan belajar. Jurnal Ilmiah Pendidikan Sosial Antropologi. 2015;5(2):1-15.

[25]Lestari MI. Persepsi orang tua terhadap pentingnya calistung untuk anak usia 5-6 tahun di TK Kartika IX-35 Jember. Indonesia (ID): Universitas Jember; 2019.

[26] Husnaini N, Jumrah. Kegiatan mewarnai sebagai stimulasi perkembangan kognitif anak usia dini. Jurnal Pendidikan Islam Anak Usia Dini. 2019;3(2):122-33.

[27] Kusumaningtyas LE. Memandirikan belajar anak TK melalui bimbingan belajar. Jurnal Ilmiah Widya Wacana. 2010;6(3):289-312.

[28] Ministry of Education and Culture. Peraturan menteri pendidikan dan kebudayaan Republik Indonesia Nomor 44 Tahun 2019. Indonesia (ID): Ministry of Education and Culture; 2019 Dec. 25 p. Report No: 44.

[29] Adandi GR, Mariyati LI. Uji validitas BenderGestalt Test dengan menggunakan Nijmeegse Schoolbekwaamheids Test (NST) sebagai kriteria untuk mendeteksi kesiapan anak masuk sekolah dasar. INSAN: Jurnal Psikologi dan Kesehatan Mental. 2017 [cited 2020 Sept 20];2(2):84-95. Available from: https://e-journal.unair.ac.id /JPKM /article/viewFile/6122/5114 DOI: 10.20473/jpkm .v2i22017.84-95.

[30] Damayanti AK, Kristianti EP. Kesiapan anak masuk sekolah dasar ditinjau dari pola asuh orang tua. Psikovidya. 2017 March [cited 2020 Sept 11];20(2):40-52. Available from: http://psikovidya. wisnuwardhana.ac.id/index.php/psikovidya/article/ view/16. 